\title{
AGENDA FOR MARKETING EXCELLENCE IN THE DEREGULATED PETROLEUM DOWN-STREAM SECTOR
}

\author{
Oluseye Olaleke OGUNNAIKE \\ College of Business and Social Sciences \\ Covenant University, Ota \\ Ogunstate, Nigeria \\ sweetleke2000@yahoo.co.uk \\ Rowland E.K WORLU \\ College of Business and Social Sciences \\ Covenant University, Ota \\ Ogunstate, Nigeria \\ worlurek@yahoo.com
}

\begin{abstract}
Deregulation in the petroleum down-stream sector tends to be treated by the masses. Oftentimes, the fear is that it will fuel the exploitative proclivities of the petroleum marketers and constitute a leeway to corruption by government officials. For example, petroleum products may sell at prohibitive prices, at least in the short run and bureaucrats may exhibit corrupt tendencies in the process. These are genuine fears! However, there is a way out! Thus this paper is based on the imperative that the situation is not as hopeless as it may seem. It offers a marketing blueprint for the implementation of deregulation in the petroleum down-stream sector in such a manner that every stakeholder in the industry will be reasonably satisfied. Thus the marketing model of deregulation reduces conflict situations by taking into account the needs, desires and preferences of all stakeholders. It succeeded in Chile, Thailand etc. why can't it work in Nigeria?
\end{abstract}

Keywords: Deregulation, Petroleum Down-Stream Sector, Marketing

JEL classification: M31, L43, P22

\section{INTRODUCTION}

A global oil market has evolved significantly, and so has become so competitive that it is setting generally accepted prices for crude and refined products.

In many countries of the world, especially the developing countries, structural reform of petroleum markets has become a critical component of macroeconomic liberalization policies. The implication is that the role of the government in the petroleum product is being defined and markets are being deregulated. In other words, state interventions such as special treatments of state-owned oil companies, price controls and restriction to trade are being 
removed and monopolies are being broken up. Increasingly, the private sector is participating in more competitive petroleum markets.

If it is to be successful, such structural reform must be in congruence with certain marketing requirements, or what may be called 'minimal but effective "new-style" regulation'.

Drawing on the recent experience of several Latin American and Caribbean (LAC) and Sub-Saharan Africa (SSA) countries, this paper lays the groundwork for the successful implementation of the structural reform in the Nigeria Petroleum Industry. It begins with a cursory look at the concept and nature of marketing in the petroleum industry, particularly in regulated regime. Based on this, it goes on to articulate the critical success factors in a deregulated petroleum industry.

\section{THE CONCEPT AND NATURE OF MARKETING IN THE PETROLEUM DOWN-STREAM SECTOR}

Marketing has for some decades now, been a subject of varied views from authorities. Despites the divergences of views, certain distinct concepts emerge as a recurring decimal in all definition. One holds that marketing is a societal activity. The other holds that marketing is essentially an economic activity concerned with the execution of those business functions that direct the flow of goods and services from the producer to the consumer. Marketing means human activity taking place in relation to markets (e.g. petroleum) to actualize potential exchange for the purpose of satisfying human needs and wants.

The petroleum business, like other social institutions owes its existence, success and growth to the application of the marketing concept. For example, Oando flagged off a nationwide marketing campaign tagged, "The Oleum Master Drive Road Show" for its newly introduced Oleum range of lubricants in early 2005. Oleum lubricants were presented at designated mechanic villages and commercial garages. Explicit Communications was the marketing consultant to Oando.

\section{THE MARKETING CONCEPT PROCESS}

What process has Oando (a major petroleum product marketer) gone through in launching the product? It started by identifying the drivers for the needs for lubricating oil that will lubricate certain parts of auto engine and driving a worthwhile experience. This identification must have included the purchasing ability, willingness and number of prospective customers (motorists and mechanics) before mass-producing or commercializing the product.

Conceptually, therefore, marketing begins with an identification of an opportunity to provide a customer service or product for which a significantly large number of people are ready to a profitable price and the mobilization of resources to provide that services. Thus, a business starts with an awareness of customer needs, finding what those needs are, developing a product or service and informing the customers of the existence, price and place of availability of the products or services.

Prior to September 30, 2003, however, when deregulation policy was announced, the practice of marketing in the Nigerian petroleum industry had not been quite impressive and was essentially characterized by the following:

> REGULATORY REGIME: In the past, pipelines and product marketing company (PPMC) monopolized the supply of petroleum products and merely supplied to whoever they chose. There was no level playing field for operators. For instance, 
it insisted that independent marketers pay for products in advance whereas the major marketers enjoyed 30-day credit for products lifted from the depot. This development was a discouragement to the development of local enterprise. Besides the government determined the pump price of oil ( pms, diesel, kerosene). This policy was only tenable in some states like Lagos and Rivers while n some other states it was like a black market case. For example, when the official price of pms (petrol) was $\mathrm{n} 34$ per litre, it only applied to Lagos. In a place like Akwa-Ibom, a litre was sold for N70. This shows that the regulatory regime was a failure.

$>$ SUBSIDY: It is an open axiom that petroleum products were heavily subsidized for the Nigerian masses before deregulation policy came into force. Although government is still making a claim of partial subsidy, this cannot be compared to what it was before now.

$>$ ROLE OF GOVERNMENT: The regulatory role of government constituted a serious impediment to the operation of demand and supply. In most cases, the government interfered with policies that were at best a disincentive to oil product marketers.

> SELECTIVE DISTRIBUTION: The products were not available in all the nooks and crannies of the country. The protagonists of deregulation have capitalized on this point to argue that a deregulated regime will make filling stations available in almost all the villages in Nigeria. Besides, such market reform would remove monopoly from few individuals and keep price at the lowest possible level. What this offers is high volume and very low margin because a lot of people will be having the same product and many will be under pressure to sell at any price. The impetus may arise from the need to pay back loan raised for sourcing the product abroad and other associated cost.

$>$ BLACK MARKET AND SMUGGLING: This was the order of the day as people smuggled the products across the borders where economic pricing was in force. Again black marketing the product scarce and expensive. But with deregulation, no black market will exist anymore and no smuggling as situation in the international market will be reflected in the home market.

$>$ INEFFICIENT REFINERIES: There were four refineries in existence, yet no one functioned efficiently, owning to corruption. President Obasanjo informed the nation in a nationwide broadcast that billons of US dollars meant to reactivate the refineries did not get there during the regime of his predecessor.

$>$ LABOUR ISSUE: Every attempt made in the past to increase the price of petroleum products had been resisted by the labour force. Besides, the work force had been opposed to deregulation because of the fear that it would throw people out of job. This is only possible in the short run. In the long run, more employments will be created because more enterprising investors will emerge.

$>$ DISTRIBUTION NETWORK: As indicated earlier on, the down stream sector refers to petroleum products, refining, distribution and marketing. It includes facilities like refineries, depots, pipelines network, petrochemical plants, as well as marketers and transporters of petroleum products. The distribution network of petroleum products before the deregulation policy can be depicted as follows; 


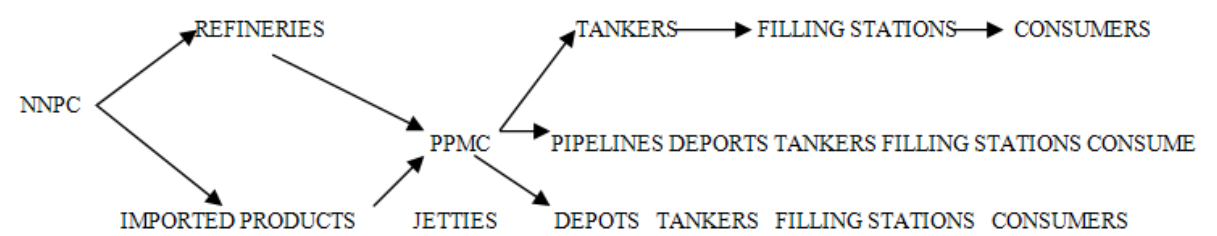

Figure no. 1 Distribution network for petroleum products

The Nigerian National Petroleum Corporation (NNPC) is an agency of government responsible for petroleum resources. It controlled the crude, refined and imported products. It was also in control of refineries and PPMC-pipelines and product marketing company.

The PPMC is the arm of NNPC charged with the responsibilities of marketing petroleum products in the domestic markets. The depots and pipeline network are directly managed by PPMC.

The government determined the quantity of crude oil to be refined per day through NNPC. The NNPC shared the required quantity of crude oil to be refined per day to each of the four refineries (Port Harcourt, Warri and Kaduna) depending on their capacities.

As at 1997 , the quantity of crude oil refined per day was 250,000 barrels. After refinement, the product is handed over to PPMC to distribute to different sales point.

A combination of different channels of distribution is utilized as shown in figure 2 above. The same is true of transportation. For example, in Port-Harcourt Refinery as at 1997, about $10 \%$ of total output was distributed through tankers to Lagos and the neighbouring states, about $30 \%$ by pipelines and the rest by sea-jetties and vessels to Lagos and Calabar.

\section{THE ESSENCE OF DEREGULATION IN THE PETROLEUM INDUSTRY}

Deregulation is the absence of regulation from a previously regulated industry or a sector of an industry. It may be the process of regulations or other barriers that restrict an industry. Hofsar (2002) (as sited in Adidu and Oghene (2005)) opined that deregulation consists in a shift to a competitive economic climate by reorienting and or suppressing regulatory mechanism.

In other words, deregulation is the process of decreasing or eliminating government regulatory control over industries. The idea is to allow competitive forces to drive the market or rather allow the market to function more freely.

Deregulation has become inevitable $\mathrm{n}$ our petroleum down streams sector due to the despicable performance of our refineries. The refineries have been working below capacity up to 2003 when deregulation in the sector was announced. The total capacity of all our refineries put together is 445,000 barrels per day (bpd) and our estimated domestic consumption is 300,000 -an excess of $145,000 \mathrm{bpd}$. But the refineries hardly operate at $50 \%$ of installed capacity." Igbudu (2000) (as cited in Adidu and Oghene (2005)". Consequently, actual capacity is $50 \%$ of 445,000 bpd or 225,000 , a shortfall of $77,500 \mathrm{bpd}$. Because of the lack of alternative domestic refineries such as the private sector production and supply, it means in effect that the government must import the shortfall.

But government cannot continue to import shortfall because of its cost implication, neither does it have the technical know-how to run a refinery. To enable government con- 
centrate on its primary responsibilities, which is politics or governance, it became imperative to deregulate this sector.

With deregulation in place, the oil company will give us petroleum products because the have the knowledge: technical and scientific knowledge to do so. Skilled labour will be employed based on performance and productivity and not on nepotism or federal character. Besides, corruption, which is endemic in our national life, will reduce.

Furthermore, the colossal amount of money, which the government spends on subsidy, will now be channeled to other capital projects; and every other anomaly usually associated with regulated regime will naturally fizzle out. It is on this premise that deregulation became the best bet.

\section{MARKETING REQUIREMENTS FOR THE SUCCESS OF DEREGULATION IN THE PETROLEUM DOWN STREAM SECTOR}

In view of the fact that marketing seeks for the satisfaction of both the investors and the consumers, the following variables below are articulated as the critical success factors for deregulation policy in the petroleum down stream sector.

A. PROCUREMENT AND REFINING: The procurement of crude oil and its products should be open to competition. This is critical to successful reform because it gives qualified importers and exporters of crude oil and products the latitude tom source them anywhere and they are considered cheaper to sell at the domestic markets. This will make local refineries to face competitions for efficiency.

> PRICE CHANGES AND TAXATION: Deregulated downstream requires adequate industry facilities and a change in pricing policy. To attract new entrants into the market, product prices (before taxes) have to be set by the market in line with economic border prices and the taxation regime must not discriminate between local and foreign suppliers. However, transitory pricing formulas can be used to stimulate import-export parity prices during a short period before prices are deregulated fully.

$>$ TEMPORARY PROTECTION: Protected operations such as uneconomic refineries operating under cost-plus systems must adapt or disappear. Such protectionism, even for security reasons, is no longer justified. However, where investments for improving existing facilities make common sense, temporary (explicit or implicit) tax protection could be granted. This was the case recently in Kenya and Cameroun as part of the World Bank adjustment programmes. Right now in Nigeria, we have refineries that cannot produce up to their installed capacities and yet government is wasting funds $\mathrm{n}$ them. Protectionism is therefore not justified in this case.

B. DISTRIBUTION AND SALES: Downstream reform can also result in competition among wholesale distributors and retail outlet. Such reform is possible even in small markets if transport is free and common-carriers principles are introduced while also respecting minimal safety and environmental regulations.

KEY CONDITIONS FOR SUCCESS AT THE RETAIL MARKETS (FILLING

STATIONS):

$>$ Transport and Storage facilities must be sufficient to cope with demand

$>$ Requirements for investors to enter the market must be simplified 
$>$ Minimal regulations must be enforced regarding product quality, safety and environmental standards including liabilities for all agents in the supply chain; and

$>$ Prices need to reflect differences in regional transports costs and market size.

THE TAKE-OFF POINT FOR RETAIL MARKETS:

For structural reform to be continually sustained at the retail markets level, the government needs to provide for competition on a permanent basis by privatizing the distribution and retail facilities. The government should design carefully the steps required to introduce economic pricing at this level, before removing state price controls to ensure that private operators remain in the market.

\section{GENERIC PRICING AND INSTITUTIONAL ISSUES:}

A good understanding of the vast interest of the petroleum industry and a welldesigned and articulated political commitment are essential for structural reform. The price liberalization-taking place in Honduras provides insight into the typical stages of a deregulation process. After a first phase in which procurement was opened to competition that brought the closure of the Texaco refinery, the government introduced a price formula reflecting import parity values and generous margins for terminal and retail operators. The effect of this is that investments in terminals increased astronomically.

There is need for consistency in government policies, effective communication, and absence of corruption, political stability and security. Again, prices need to be corrected, a new regulatory framework put in place, and certain key conditions met during a transitory period to ensure that a truly competitive market is established. These issues will be discussed in turn.

$>\quad$ Need for Consistency in Government Policies: Inconsistency policies are counterproductive in the investment world. This is because investors would be reluctant to invest in a system where government policies change often. In such a system, deregulation would not achieve much as investors will view incentives offered by government with scepticism.

$>$ Effective Communication: Deregulation of the petroleum market is a particularly sensitive issue to Nigerians. The reason is not far-fetched! Nigeria is a monocultural economy depending preponderantly on oil gas. The people have imbibed over the years, the feeling that petroleum is a God-given resource, which ought not to be paid for, let alone at high price. To change this position will require tact and patience on the part of government, while at the same time, using appropriate and several media to communicate the brighter side of deregulation to the people.

$>$ Political Stability and Security: This constitutes another important requirement for the success of deregulation in the petroleum downstream sector. This is because economic activities or more strictly the petroleum markets are situated within a political framework. Therefore, investors (both local and foreign) will need to be guaranteed of the security of their investment in any deregulation. In Nigeria, enthronement of democracy is a commendable step toward political stability but the issue of security is yet to be resolved. The conflict in the Niger-Delta region of the country confirms this point.

$>$ Absence of Corruption: Deregulation will succeed in an environment that has zero-tolerance for corruption. The acute situation of corruption in our country is already casting doubt on the prospect of the deregulated downstream sector. 
When the prices of petroleum products were minimal, illegal oil bunkering was already gaining ground. In most cases, suspects went scot-free due to corruption. Proceeds of illegal bunkering were often shared among the bunkers, top government officials and security operatives in the country. Deregulation, which increases the price of petroleum products in the short-run, seems to be an incentive to corruption via illegal bunkering. Government is therefore called upon to enforce the anti-corruption provision of the criminal code in order to make the deregulation of the petroleum downstream sector a success.

$>$ Ensure Correct Price Signal: Price signaling can play a crucial role in deregulation. Products prices and margins need to provide correct signals to producers and consumers. Price distortions such as subsidies and taxation need to be reviewed. In addition, downstream taxation must not differentiate between local and foreign supplies or between fuels. As regional integration progresses, crossborder prices will become increasingly harmonized and hence fewer products will be smuggled.

$>$ Introduce Minimal Regulation: To do this effectively, the following four issues should be considered;

* Policy formulation responsibilities and regulatory functions need to be assigned to different agencies. For example, the Department of Petroleum Resources (DPR) and some other government agencies will still be relevant.

* Barriers to enter the local market need to be abolished (in particular, unnecessary legal and administrative procedures to build and operate new facilities)

* Open access needs to be introduced to monopolistic facilities (such as marineterminal, storage facilities and pipelines) through nondiscriminatory tariffs; and

* Quality standards need to be set for products that take into account the market characteristics and maximize the number of supply resources. In Chile, policy and regulatory responsibilities are vested upon different government agencies; and barriers to competition are eliminated.

$>$ Create Condition for Competition: It takes time to create the minimal conditions for competition. This depends on the location of the country, the size of the market and the overall macroeconomic programme. It also takes time for the market to respond to new competitive conditions. During the transition, the following features are essential:

* A certain number of players must be ready to operate (the number depends on the size of the market)

* Relation with private companies needs to be handled sensitively by the government. Qualified operators should provide their financial and technical capacity, be liable for environmental and safety regulations and keep a minimum security stock; and

* A regulatory entity must be established to monitor the market and to react rapidly to any deterioration of product quality or non-competitive behaviour. 


\section{CONCLUSIONS}

The deregulatory policy as it affects the petroleum downstream sector presumes that the distribution network operated during the regulated regime in which NNPC (through PPMC) was the sole source of supply will no longer be tenable. However, oil marketers should enjoy sufficient access to facilities (like pipelines, depots, jetties, etc) on commercial basis.

Be that as it is, the petroleum business enjoys the stake of every Nigerian. For the deregulation policy to succeed, all stakeholders (i.e. community, government, investors, consumers, etc) must be duly considered. This consideration is only guaranteed in the TOTAL MARKET CONCEPT whose pre-occupation is the satisfaction of the customer as well as other stakeholders. If the blueprint proposed in this paper is implemented on this platform, every misgiving about deregulation policy will certainly subside.

\section{References}

[1] Achumba, I.C (2000) Strategic Marketing Management In The $21^{\text {st }}$ Century, Charlotte; MacWilliams Publishers Inc

[2] Adedu \& Oghere (2005) Deregulation As A Tool To Economic Advancement and Societal Progress: Oil, The Nigeria Experience

[3] Atare Otite (2005) "Deregulation And Casualization Of Workers in the oil sector in Nigeria" in Akpator, A.S et al (2005) Deregulation and Globalization in Nigeria: Issues and Perspectives (eds) Ekpoma, Ambrose Alli University Publishing House.

[4] Braide, K.M (2005) "Modes of Deregulation in the Downstream Sector of the Nigerian Petroleum Industry". Published at: www.nigerdelta congress.com

[5] Echebiri, R (2004) "Rising Oil Prices As A Crisis", Financial Standard, September

[6] Ejiofor, N.O.P (1998) "Guidelines For Future Management Of The Nigerian Economy", in Nigeria: The first 25 years, Lagos: Infordata Ltd

[7] Margarito, B. (1995), Deregulation: Myth or Fact? (On-line serial) http://www.geocities.com/afdb.spotsorteves.atm

[8] Ndiribe, O (2003) "Deregulation of Nigeria Petroleum Industry Lack A Human Face". www.gasandoil.com/gol/welcome.html!

[9] Nnamani, C (2003) "Lectures on Deregulation" www.ebeano.org

[10] Olugbemi, S (2001) "Nigeria Energy Sector Privatization would Depend On Clear Policy: www.gasandoil.com/gol/nwws/nta/2274.htm

[11] Olusegun Obasanjo (2003) Presidents' Speech at the Inauguration of Petroleum Product Pricing Regulatory Agency, Abuja, June

[12] Omoregie, V.N. (2003, October 8) "How not to Deregulate" The Guardian. Pp 30-31 Prospect for Nigeria's Downstream Oil Industry (petroleum product central unit at www.nigsiafirst.com)

[13] Worlu, R.E. (2005) Doom in Nigeria's Oil Boom-A paper presented at Covenant University Staff Parley, Ota, May 